\title{
A study on the association of cervical spondylosis severity, as indicated by cervical motions, with hearing impairment
}

\author{
Bashaer Hameed Karam ${ }^{1}$, Hussain S. Hasan ${ }^{1}$, Hassan Thabit Saeed ${ }^{2}$ \\ 1 Department of Physiology and Medical Physics, College of Medicine, Al-Nahrain University, Kadhimiya, Baghdad, Iraq; \\ 2 Department of Audiology, Al-Imamein Al-Kadhimein Medical City, Kadhimiya, Baghdad, Iraq
}

\begin{abstract}
Study aim: The present study investigates the possible relation between the limitation of cervical motion in a patient with cervical spondylosis and hearing impairment.

Material and methods: Cross-sectional research was performed based on 60 participants suffering from cervical spondylosis (CS) selected from an orthopaedic and physiotherapy department. The data collection techniques included questionnaire, electronic tools, measurements with a mechanical device including measuring the cervical range of motion (ROM) by goniometer, and physical examination including pure tone audiometry (PTA) and tympanogram.

Results: Right rotation was the most common limitation, which affected 43 patients, followed by left rotation limitation, which was recorded in 40 patients. The extension, left lateral flexion, flexion, and right lateral flexion limitation showed less effect.

Conclusions: Left rotation limitation was found to be an independent predictor of hearing impairment especially in men. Age was also a risk factor for sensory neural hearing loss (SNHL). These findings are important in the facilitation of investigating SNHL in cervical spondylosis patients.
\end{abstract}

\section{Keywords: Hearing loss - Hearing impairment - Cervical spondylosis - Pure tone audiometry - Range of motion}

\section{Introduction}

Cervical spondylosis (CS) is a progressive degeneration of the intervertebral disc, leading to a change in peripheral structures [3]. Generally, it is caused by daily wear and tear with a combination of various injuries sustained during life leading to a breakdown of healthy tissue [19].

The consequence of degenerative cervical spine is initiated with loss of integrity of intervertebral disc, as the disc becomes more aged. Thus, the nucleus pulposus fragment collapses and loses water. Bulging of the disc and loss of the disc height biomechanically leads to a decrease of the weight-bearing capacity. Abnormal forces and motion can then cause bone formation, which leads to creating osteophytic bars that extend with the ventral portion of the spinal canal. Also, these osteophytic bars may encroach on nervous tissue, thus leading to compression of the nerve roots or the spinal cord [18].

In 1985, Palmer originated the idea of the association of a vertebrogenic hearing disorder that is accompanied with a feeling of ear pressure, tinnitus, otalgia and hearing impairment due to the functional deficit of the upper cervical spine. Subsequent studies discuss the possibility of hearing improvement after having chiropractic technique for patients who suffer from cervical injuries $[5,9,17]$.

The degenerative process of the cervical vertebra obstructs the blood feeding to the ear either by narrowing the pathway of the vertebral artery which is the source of the anterior inferior cerebellar artery (AICA) and the basilar artery which is responsible for supplying the blood to the inner ear [4], or by the compression effect of the osteophyte on the nerve roots and the vertebral artery; in both cases, it may lead to hearing loss (HL), tinnitus or both.

Other studies discuss the hearing impairment following a cervical spine disorder (such as disk herniation at cervical upper segments, rheumatoid arthritis, osteoarthritis) as well as numerous investigations and studies such as that of Huang in 2017, a retrospective cohort study at China Medical University Hospital about the risk of hearing impairments in RA patients. They identified 18267 patients 
with RA, and they identified 73068 persons without RA. The study showed that RA patients had nearly doubled probability of developing a hearing impairment than those without RA. Furthermore, they confirmed that hearing loss risk is related to RA rising with age [11], while Rkain et al. [16] found that HL was more prevalent in patients with RA compared to healthy groups. Among RA patients $43.4 \%$ had conductive hearing loss, 3.3\% sensorineural, and 10\% mixed hearing loss. Also Emamifar et al. [7] suggested an increase in the risk of hypoacusis for patients with RA in the course of the disease when compared to healthy participants, and other studies $[1,14]$, but no specific study for CS and its limitations.

The main objective of the present study is to evaluate the relationship between CS and hearing impairment and the most important cervical limitation in this association. This would be a new frontier that would probably open the door for new studies that may help in reducing HL resulting from CS and its limitation.

The hypothesis of this study was that there is a relation between cervical spondylosis limitations and hearing impairment.

\section{Material and methods}

A cross-sectional study was performed in 60 participants suffering from cervical spondylosis selected from the orthopaedic and physiotherapy department. Informed consent was obtained from all participants.

The inclusion criterion was any conscious patient with cervical spondylosis disease, while the exclusion criteria were: Meniere's disease, ear operation, trauma of the ear, middle ear effusion, tympanic membrane perforation, and any patient with previous hearing loss.

The procedure adopted included a questionnaire to collect the demographic data (for determining age, gender, family history, occupational noise, and smoking), electronic mechanical device (measuring ROM, blood sugar, blood pressure, and body mass index [BMI]), and physical ear examination.

The cervical ROM was measured by goniometer to determine the degree of motion for each cervical movement: flexion, extension, right or left lateral flexion, and right or left rotation [15].

The considered degrees for a normal range of motion were: flexion up to 80 degrees, extension up to 70 degrees, 45 degrees for lateral flexion and up to 90 degrees for rotation.[21]

Pure tone audiometry (PTA) examination was performed in a specially designed sound-attenuating test room to determine the type and degree of hearing loss for frequencies ranging from 250 to $8000 \mathrm{~Hz}$. The usual PTA value is calculated by averaging: $500+1000+2000 \mathrm{~Hz} / 3 \geq 25 \mathrm{~dB}$ [13].
But we selected these three averages for calculating the hearing threshold:

(1) $500+1000+2000 \mathrm{~Hz} / 3$

(2) $500+1000+2000+4000 \mathrm{~Hz} / 4$

(3) $250+500+1000+2000+4000+8000 \mathrm{~Hz} / 6$

These averages are useful for participants with normal PTA (commonly using the first average $500+1000$ $+2000 \mathrm{~Hz} / 3$ ) but they have high frequencies loss only; in other words when these averages gradually increase it means the high frequencies are more impaired than the low frequencies.

However, the tympanogram was selected to make sure that there was no middle ear dysfunction. The results were classified as types A, As, Ad, B, and C according to Jerger [22].

Patients were categorized according to limitation into two categories: with and without limitation and the hearing threshold (HT) at three levels of pure tonic audiometry (PTA) was compared between the two groups.

SPSS software version 25.0 and Microsoft Excel were used for statistical analyses and graph creation. Numerical variables were expressed as mean \pm standard deviation (SD), while binomial variables were expressed as frequency and percentages. Student's t-test was used to compare means between two groups (with and without limitation), while analysis of variance (ANOVA) was used to compare more than two groups. The correlation between numerical variables was done using Spearman correlation. Different risk factors were entered into the multilinear regression model to determine the independent risk of hearing impairment. Results were considered statistically significant when having $\mathrm{p}$-values $\leq 0.05$.

\section{Results}

Mean age of participating patients was $49.22 \pm 12.96$ years, and exactly half of them were male. The BMI ranged from 19.4 to as high as $42.2 \mathrm{~kg} / \mathrm{cm}^{2}$ (mean $30.22 \pm 5.42$ $\mathrm{kg} / \mathrm{cm}^{2}$ ). Mean systolic blood pressure (SBP) and diastolic blood pressure (DBP) were 133.22 $\pm 19.49 \mathrm{mmHg}$ and $80.92 \pm 9.0 \mathrm{mmHg}$ respectively. Diabetes mellitus (DM) was reported in 7 patients $(11.67 \%)$, while a family history of hearing impairment among cervical spondylosis patients was reported in 10 patients (16.67\%). Eighteen patients $(30 \%)$ declared that they were exposed to occupational noise, and 8 patients $(13.33 \%)$ were either current or ex-smokers.

\section{Types and frequency of range of motion limitation among the patients}

The study involved six ROM limitations as shown in Figure 1. Right rotation was the most common limitation, affecting 43 patients, followed by left rotation limitation, which was recorded in 40 patients. Extension limitation 


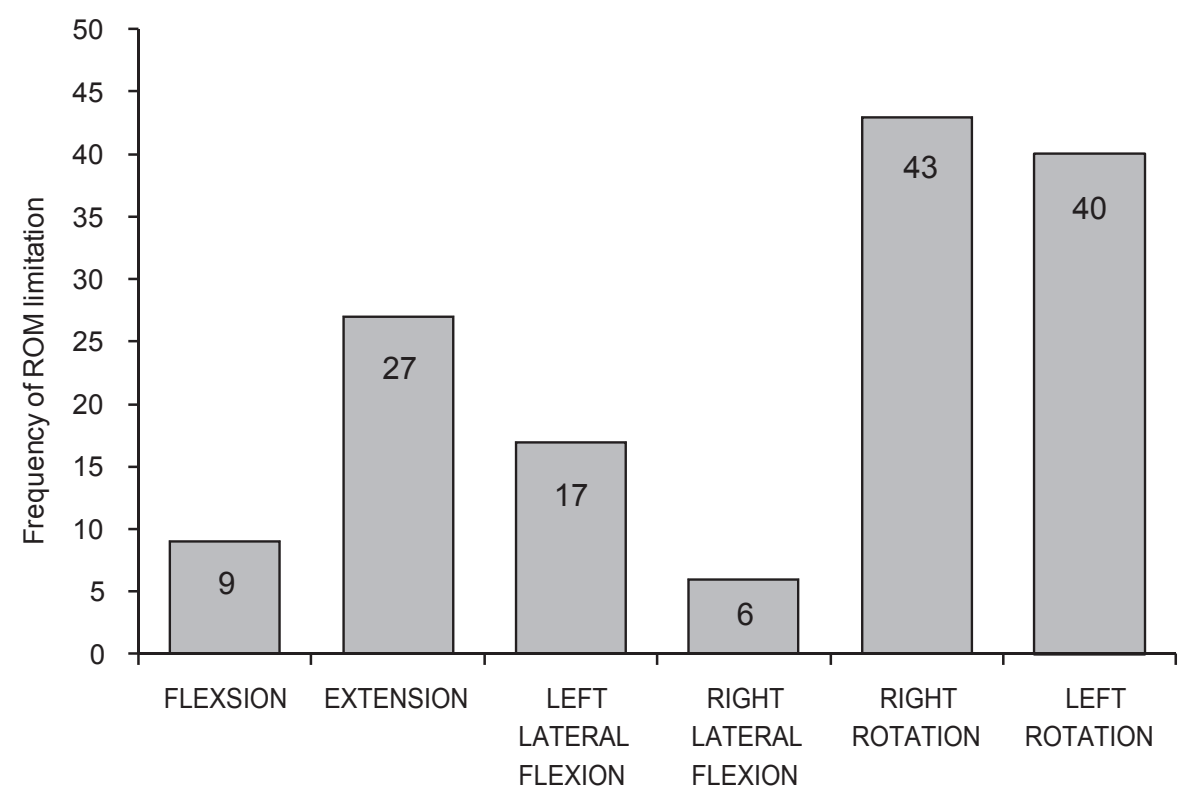

Figure 1. Types and frequency of range of motion limitation among the patients

came next with 27 frequencies followed by left lateral flexion limitation (17 patients). Limitation in flexion and in right lateral flexion was less encountered and was reported in 7 and 6 patients respectively.

All in all, no significant differences were noted in HT at different PTA levels between the patients with and those without flexion limitation, which is neither in the right ear nor in the left ear.

For the right ear in overall patients, mean HT at both PTA2 and PTA3 $(25.26 \pm 8.3 \mathrm{~dB}$ and $27.48 \pm 8.35 \mathrm{~dB}$ respectively) in patients with extension limitation was significantly higher than in patients without extension limitation $(21.82 \pm 7.3 \mathrm{~dB}$ and $23.33 \pm 7.9 \mathrm{~dB}$ respectively) (see Table 1).

For the left lateral flexion limitation, only two significant associations were reported, both of them in the left ear at the mPAT2 level.

On the other hand, for the right lateral flexion limitation, only two significant associations were reported, both of them in the right ear at the PAT1 level.

Table 1. Association of extension limitation with hearing threshold

\begin{tabular}{|c|c|c|c|c|c|c|c|c|c|}
\hline \multirow[t]{2}{*}{ Groups } & \multirow[t]{2}{*}{ Status } & \multirow[t]{2}{*}{ No } & \multicolumn{3}{|c|}{ Right ear } & \multicolumn{3}{|c|}{ Left ear } & \multirow[t]{2}{*}{ Total average } \\
\hline & & & PTA1 & PTA2 & PTA3 & PTA1 & PTA2 & PTA3 & \\
\hline \multirow{3}{*}{$\begin{array}{l}\text { Total } \\
\text { patients }\end{array}$} & $\begin{array}{l}\text { Without ROM } \\
\text { limitation }\end{array}$ & 33 & $\begin{array}{l}20.67 \\
\pm 5.89\end{array}$ & $\begin{array}{c}21.82 \\
\pm 7.3\end{array}$ & $\begin{array}{c}23.33 \\
\pm 7.9\end{array}$ & $\begin{array}{l}22.12 \\
\pm 8.24\end{array}$ & $\begin{array}{c}24.58 \\
\pm 10.36\end{array}$ & $\begin{array}{l}22.76 \\
\pm 9.47\end{array}$ & $24.82 \pm 9.07$ \\
\hline & $\begin{array}{l}\text { With ROM } \\
\text { limitation }\end{array}$ & 27 & $\begin{array}{l}23.41 \\
\pm 7.69\end{array}$ & $\begin{array}{c}25.26 \\
\pm 8.3\end{array}$ & $\begin{array}{l}27.48 \\
\pm 8.35\end{array}$ & $\begin{array}{c}25.41 \\
\pm 15.67\end{array}$ & $\begin{array}{c}27.85 \\
\pm 17.88\end{array}$ & $\begin{array}{c}25.85 \\
\pm 11.79\end{array}$ & $29.11 \pm 13.59$ \\
\hline & p-value & & 0.123 & 0.044 & 0.034 & 0.301 & 0.379 & 0.264 & 0.149 \\
\hline \multirow{3}{*}{ Male } & $\begin{array}{l}\text { Without ROM } \\
\text { limitation }\end{array}$ & 19 & $\begin{array}{l}19.05 \\
\pm 5.90\end{array}$ & $\begin{array}{l}20.89 \\
\pm 7.98\end{array}$ & $\begin{array}{l}22.89 \\
\pm 8.58\end{array}$ & $\begin{array}{l}21.26 \\
\pm 8.35\end{array}$ & $\begin{array}{c}24.68 \\
\pm 11.62\end{array}$ & $\begin{array}{c}26.53 \\
\pm 12.22\end{array}$ & $24.71 \pm 10.28$ \\
\hline & $\begin{array}{l}\text { With ROM } \\
\text { limitation }\end{array}$ & 11 & $\begin{array}{l}23.73 \\
\pm 9.47\end{array}$ & $\begin{array}{c}28.27 \\
\pm 11.65\end{array}$ & $\begin{array}{c}30.46 \\
\pm 11.73\end{array}$ & $\begin{array}{c}31.27 \\
\pm 16.09\end{array}$ & $\begin{array}{c}35.73 \\
\pm 23.74\end{array}$ & $\begin{array}{c}39.64 \\
\pm 23.49\end{array}$ & $35.05 \pm 17$ \\
\hline & $\mathrm{p}$-value & & 0.105 & 0.049 & 0.032 & 0.025 & 0.097 & 0.033 & 0.046 \\
\hline \multirow{3}{*}{ Female } & $\begin{array}{l}\text { Without ROM } \\
\text { limitation }\end{array}$ & 14 & $\begin{array}{l}22.86 \\
\pm 5.32\end{array}$ & $\begin{array}{l}23.07 \\
\pm 6.33\end{array}$ & $\begin{array}{l}23.93 \\
\pm 7.16\end{array}$ & $\begin{array}{l}23.29 \\
\pm 8.25\end{array}$ & $\begin{array}{l}24.43 \\
\pm 8.79\end{array}$ & $\begin{array}{c}26 \\
\pm 9.62\end{array}$ & $24.96 \pm 7.48$ \\
\hline & $\begin{array}{l}\text { With ROM } \\
\text { limitation }\end{array}$ & 16 & $\begin{array}{l}23.19 \\
\pm 6.52\end{array}$ & $\begin{array}{l}23.19 \\
\pm 6.94\end{array}$ & $\begin{array}{l}25.44 \\
\pm 8.16\end{array}$ & $\begin{array}{l}21.38 \\
\pm 7.59\end{array}$ & $\begin{array}{l}22.44 \\
\pm 10.1\end{array}$ & $\begin{array}{c}24.63 \\
\pm 11.13\end{array}$ & $25.03 \pm 9.16$ \\
\hline & $\mathrm{p}$-value & & 0.881 & 0.962 & 0.591 & 0.514 & 0.572 & 0.722 & 0.983 \\
\hline
\end{tabular}


Likewise, mean HT in patients with left rotation limitation at PTA2 and PTA3 for the left ear was 28.07 $\pm 14.97 \mathrm{~dB}$ and $30.88 \pm 15.4 \mathrm{~dB}$ respectively, which are significantly higher than in corresponding patients without left rotation limitation $(20.94 \pm 10.84 \mathrm{~dB}$ and $21.76 \pm 11.34 \mathrm{~dB}$ respectively). However, in the male group, exactly the same associations were significant, with minor changes in the means of HT (see Table 2).

For the last limitation, only two significant associations were found in right rotation limitation, both in the right ear at the PTA1 level.

\section{Correlations between quantitative variables}

Spearman's correlation test was used to explore the possible correlations between quantitative variable. For total patients, the overall mean HT had a positive significant association with each of age $(r=0.724, p<0.001)$, SBP $(\mathrm{r}=0.495, \mathrm{p}<0.001)$, and DBP $(\mathrm{r}=0.291, \mathrm{p}=0.024)$, as shown in Table 3.

\section{Association between HT and qualitative variables}

Two variables were found to have a close association with HT. Patients with DM had significantly higher mean HT.

Table 2. Association of left rotation limitation with hearing threshold

\begin{tabular}{|c|c|c|c|c|c|c|c|c|c|}
\hline \multirow[t]{2}{*}{ Groups } & \multirow[t]{2}{*}{ Status } & \multirow[t]{2}{*}{ No } & \multicolumn{3}{|c|}{ Right ear } & \multicolumn{3}{|c|}{ Left ear } & \multirow[t]{2}{*}{ Total average } \\
\hline & & & PTA1 & PTA2 & PTA3 & PTA1 & PTA2 & PTA3 & \\
\hline \multirow{3}{*}{$\begin{array}{l}\text { Total } \\
\text { patients }\end{array}$} & $\begin{array}{l}\text { Without ROM } \\
\text { limitation }\end{array}$ & 17 & $\begin{array}{l}20.12 \\
\pm 5.92\end{array}$ & $\begin{array}{l}19.71 \\
\pm 6.89\end{array}$ & $\begin{array}{l}20.71 \\
\pm 7.47\end{array}$ & $\begin{array}{l}20.12 \\
\pm 8.08\end{array}$ & $\begin{array}{c}20.94 \\
\pm 10.84\end{array}$ & $\begin{array}{c}21.76 \\
\pm 11.34\end{array}$ & $\begin{array}{l}21.26 \\
\pm 9.24\end{array}$ \\
\hline & $\begin{array}{l}\text { With ROM } \\
\text { limitation }\end{array}$ & 43 & $\begin{array}{c}22.6 \\
\pm 7.11\end{array}$ & $\begin{array}{l}24.81 \\
\pm 8.53\end{array}$ & $\begin{array}{l}26.98 \\
\pm 9.34\end{array}$ & $\begin{array}{c}24.98 \\
\pm 13.26\end{array}$ & $\begin{array}{c}28.07 \\
\pm 14.97\end{array}$ & $\begin{array}{l}30.88 \\
\pm 15.4\end{array}$ & $\begin{array}{c}28.93 \\
\pm 11.57\end{array}$ \\
\hline & $\mathrm{p}$-value & & 0.207 & 0.032 & 0.017 & 0.165 & 0.04 & 0.031 & 0.017 \\
\hline \multirow{3}{*}{ Male } & $\begin{array}{l}\text { Without ROM } \\
\text { limitation }\end{array}$ & 9 & $\begin{array}{c}18.9 \\
\pm 6.64\end{array}$ & $\begin{array}{l}18.78 \\
\pm 8.1\end{array}$ & $\begin{array}{l}19.78 \\
\pm 8.53\end{array}$ & $\begin{array}{l}20.44 \\
\pm 9.86\end{array}$ & $\begin{array}{c}21.56 \\
\pm 13.83\end{array}$ & $\begin{array}{c}21.9 \\
\pm 13.57\end{array}$ & $\begin{array}{c}20.83 \\
\pm 10.91\end{array}$ \\
\hline & $\begin{array}{l}\text { With ROM } \\
\text { limitation }\end{array}$ & 21 & $\begin{array}{c}21.57 \\
\pm 8.0\end{array}$ & $\begin{array}{l}25.67 \\
\pm 9.14\end{array}$ & $\begin{array}{c}28.19 \\
\pm 10.76\end{array}$ & $\begin{array}{c}26.86 \\
\pm 13.83\end{array}$ & $\begin{array}{c}31.81 \\
\pm 18.33\end{array}$ & $\begin{array}{c}35.38 \\
\pm 18.42\end{array}$ & $\begin{array}{c}31.78 \\
\pm 13.89\end{array}$ \\
\hline & p-value & & 0.385 & 0.043 & 0.047 & 0.302 & 0.145 & 0.049 & 0.045 \\
\hline \multirow{3}{*}{ Female } & $\begin{array}{l}\text { Without ROM } \\
\text { limitation }\end{array}$ & 8 & $\begin{array}{c}21.5 \\
\pm 5.04\end{array}$ & $\begin{array}{l}20.75 \\
\pm 5.57\end{array}$ & $\begin{array}{c}21.75 \\
\pm 6.5\end{array}$ & $\begin{array}{l}19.75 \\
\pm 6.15\end{array}$ & $\begin{array}{c}20.25 \\
\pm 7.0\end{array}$ & $\begin{array}{l}21.63 \\
\pm 9.15\end{array}$ & $\begin{array}{l}21.69 \\
\pm 7.66\end{array}$ \\
\hline & $\begin{array}{l}\text { With ROM } \\
\text { limitation }\end{array}$ & 22 & $\begin{array}{l}23.59 \\
\pm 6.18\end{array}$ & $\begin{array}{c}24.0 \\
\pm 6.77\end{array}$ & $\begin{array}{l}25.82 \\
\pm 7.84\end{array}$ & $\begin{array}{l}23.18 \\
\pm 8.28\end{array}$ & $\begin{array}{l}22.24 \\
\pm 10.0\end{array}$ & $\begin{array}{c}26.59 \\
\pm 10.56\end{array}$ & $\begin{array}{l}26.21 \\
\pm 8.32\end{array}$ \\
\hline & p-value & & 0.40 & 0.236 & 0.201 & 0.296 & 0.281 & 0.25 & 0.191 \\
\hline
\end{tabular}

Table 3. Spearman correlation between different variables among the total population

\begin{tabular}{|c|c|c|c|c|c|}
\hline Variable & DBP & SBP & BMI & Age & DBP \\
\hline \multicolumn{6}{|l|}{ HT (total) } \\
\hline r & 0.291 & 0.495 & -0.103 & 0.724 & 0.291 \\
\hline p-value & 0.024 & $<0.001$ & 0.433 & $<0.001$ & 0.024 \\
\hline \multicolumn{6}{|l|}{ Age } \\
\hline $\mathrm{r}$ & 0.239 & 0.50 & -0.081 & & 0.239 \\
\hline p-value & 0.068 & $<0.001$ & 0.539 & & 0.068 \\
\hline \multicolumn{6}{|l|}{ BMI } \\
\hline $\mathrm{r}$ & 0.066 & 0.045 & & & 0.066 \\
\hline p-value & 0.619 & 0.733 & & & 0.619 \\
\hline \multicolumn{6}{|l|}{ SBP } \\
\hline $\mathrm{r}$ & 0.549 & & & & 0.549 \\
\hline p- value & $<0.001$ & & & & $<0.001$ \\
\hline
\end{tabular}




\section{Multiple regression}

Age, left rotation (ROM limitation), SBP, DBP and diabetes were significantly associated with HT and are hypothesized to interfere with ROM limitation. Thus, multiple regression was performed to determine whether ROM limitation is an independent factor affecting HT or not. Only left rotation limitation and age were found to be independent risk factors for HT.

\section{Discussion}

The present study showed a significant increase in the hearing threshold at PTA2 in the left ear at left lateral flexion limitation. Also, there was a significant increase in the hearing threshold at PTA1 in the right ear at right lateral flexion limitation. This suggests a direct relation between the side of the cervical flexion limitation (left or right) and the side of hearing impairment (left or right ear).

Limitation of cervical left rotation showed a bilateral significant increase in hearing threshold in both ears for total patients at PTA2 and PTA3 especially in male patients. That means there is a relation between the left rotation limitation (LRL) and higher frequencies, related to sensory neural hearing loss. That is confirmed by VasaghiGharamaleki, who found a significant difference between the mean hearing threshold of males with LRL and those without LRL [20]. It seems that vertigo and HL cannot be caused by the dysfunction in the lower neck (at segments lower than C3). Also, most of the cervical rotation occurs in the upper neck [8], because of the articulation between the atlas and axis allowing the cervical rotation motion. However, the limitation in the rotation motion may lead to dizziness and vertigo associated with HL [8].

The study of limitation of cervical right rotation showed a unilateral significant increase in hearing threshold in the right ear for total patients at PTA1. This implies that there is a relation between the right rotation limitation (RRL) and the hearing loss in speech frequencies $(500,1000$ and $2000 \mathrm{~Hz}$ ).

On the other hand, the study revealed significant correlations between age, blood pressure, and blood sugar with the hearing threshold. The high association of age with increasing $\mathrm{HL}$ is due to the changes in the frequency-dependent gain in the central auditory system synapses and abnormality in the function of auditory temporal processing. This degradation of auditory perception results from degeneration of the auditory nerves or the cochlea or both [6]. Age-related HL is highly widespread among older people [10]. Hypertension is associated with an increased hearing threshold because the cells in the body need an adequate supply of nutrients and oxygen to maintain their function; however, this supply depends on the proper structure and functioning of the blood vessels and heart
[12]. Hypertension in the vascular system may lead to haemorrhage in the inner ear, which is supplied by the AICA, which supports the artery of the inner ear, which may lead to progressive or sudden HL [2].

However, in multiple linear regression, only left rotation limitation and age were found to be strong independent predictors of HT.

\section{Conclusion}

We found evidence for our hypothesis that the left rotation limitation can be used as an independent predictor of sensory neural hearing loss in cervical spondylosis patients, especially in men.

On the other hand, age plays an important role in occurrence of hearing loss. Also it is considered as a risk factor for both cervical spondylosis and sensory neural hearing loss.

Conflict of interest: Authors state no conflict of interest.

\section{References}

1. Alonso L., Farfan I.G., Ayala A.P., Bastidas M.E., Espinosa R. (2011) Clinical Significance of Auditive Involvement in Rheumatoid Arthritis: A Case-Control Study. International Scholarly Research Network ISRN Rheumatology, 7.

2. Bachor E., Selig Y.K., Jahnke K., Rettinger, G., Karmody, C.S. (2001) Vascular variations of the inner ear. Acta oto-laryngologica, 121(1): 35-41.

3. Brain L., Wilkinson M. (2013) Cervical Spondylosis and Other Disorders of the Cervical Spine. UK: ButterworthHeinemann.

4. Clark C.R., Benzel E.C. (2005) cervical spine. New York: Lippincott Williams \& Wilkins.

5. Di Duro J.O. (2006) Improvement in hearing after Chiropractice care: A case serie. Chiropr. Osteopat., 14: 2.

6. Eggermont J.J. (2019) The Auditory Brain and Age-Related Hearing Impairment. Cambridge, Massachusetts: Academic Press.

7. Emamifar A., Bjoerndal K., Hansen I.M. (2016) Is hearing impairment associated with rheumatoid arthritis? a review. Open Rheumatol. J., 10: 26.

8. Haldeman S., Dagenais S. (2001) Cervicogenic headaches. Spine Journal, 1(1): 31-46.

9. Heasley J. (2006) Can you hear me know? Psychology Today, http://www.psychologytoday.com/articles/200608/ can-you-hear-me-now.

10. Homans N.C., Metselaar R.M., Dingemanse J.G., van der Schroeff M.P., Brocaar M.P., Wieringa M.H., Baatenburg de Jong R.J., Hofman A., Goedegebure A. (2016) 
Prevalence of age-related hearing loss, including sex differences, in older adults in a large cohort study. Laryngoscope, 127(3): 725-730.

11. Huang C., Chen H., Huang P., Tsay G.J., Lan J.L., Sung F.C. (2017) Retrospective cohort study on risk of hearing loss in patients with rheumatoid arthritis using claims data BMJ Open 2018, 8: e018134.

12. Katz J. (1989) Tratado de audiologia clínica. Manole: São Paulo.

13. Kramer S., Brown D.K. (2018) Audiology: Science to Practice, Third Edition. Us. North America: Plural Publishing.

14. Murdin L., Patel S., Walmsley J., Hoe Yeoh L. (2007) Hearing difficulties are common in patients with rheumatoid arthritis. Clin. Rheumatol., 27: 637-640.

15. Norkin C.C., White D.J. (2016) Measurement Of Joint Motion: A Guide To Goniometry. Philadelphia, US: F.A. Davis.

16. Rkain I., Rkain H., Bouaddi I., Dakka T., Hassouni N.H., Essakalli L. (2016) Relationship between Disease Activity and Hearing Loss in Rheumatoid Arthritis Patients A Case Control Study. Mediterranean BioMedical Journals International Journal of Medicine and Surgery, 3-5.
17. Saunders L. (2004) Chiropractic treatment of otitis media with effusion. Clinical Chiropractic, pp 158-173.

18. Shen F.H., Samartzis D., Fessler R.G. (2014) Textbook of the Cervical Spine E-Book. Edinburgh, London: Elsevier Health Sciences.

19. Sueki D., Brechter J. (2009) Orthopedic Rehabilitation Clinical Advisor - E-Book. St. Louis Missouri: Mosby Elsevier.

20. Vasaghi-Gharamaleki B., Naser Z. (2017) Predicting the risk of hearing impairment following the cervical spine diseases by measuring the cervical range of movements: A pilot Study. Basic Clin. Neurosci., 8(5): 413.

21. Windle W.F. (1980) The spinal cord and its reaction to traumatic injury. New York, NY: M Dekker; xi, 384.

22. Zouridakis G. (2003) Biomedical Technology and Devices handbook. Boca Raton, Florida: CRC Press.

\section{Received 14.10.2019 \\ Accepted 03.12.2020}

(C) University of Physical Education, Warsaw, Poland 